\title{
STUDY OF PROCESSES OF ACTIVATED CARBON OBTAINING FROM WOOD CHARCOAL
}

\author{
Silvia Cibotaru \\ Institute of Chemistry of the ASM \\ 3 Academiei str., MD 2028, Chișinău, R. Moldova \\ E-mail: silvia.popovici@gmail.com
}

\begin{abstract}
This paper presents the results of scientific research aimed at studying processes of obtaining activated carbon from wood charcoal. We presented methods for determining the structure parameters and specific surface of carbonic adsorbents. Scientific research results allow concluding that wood charcoal is a cheap and effective material for the synthesis of activated charcoal.
\end{abstract}

Keywords: wood charcoal, physico-chemical activation, activated carbons, pore volume, specific surface area.

\section{Introduction}

Active coal is a chemical of certain value, widely used in various industries: pharmaceutical, food, mining, chemical and petrochemical industries, for individual and collective protective equipment in industry and military, for the purification of wastewater, surface water and groundwater etc. A specific area where active coal is used is medicine. Carbon adsorbents are used in this area as enterosorbents and haemosorbents to detoxify the body. These utilizations of activated charcoal characterize it as a product of prime importance in economy and the production of a wide range of activated carbons is of major interest for various industries, due to their special needs.

Activated carbons are adsorbents obtained by different methods of activating the carbonized and un-carbonized raw material as a result of chemical treatment, physico-chemical and mixed treatment of raw materials. Obtained activated carbons fix and retain on their surface organic and inorganic substances they contact. They are composed of a carbon skeleton with very fine pores and channels of varying depths and diameters; on these surfaces takes place the concentration of adsorbed substances [1].

The most commonly used is the physico-chemical activation process, which is based on the interaction of oxygen, carbon dioxide or water vapor with heavy hydrocarbons that fill the pores of carbonized material subjected to activation and/or amorphous carbon atoms in charcoal skeleton. The mentioned procedure shall apply only in the case of carbonized vegetal substances. As an example can serve the wood charcoal from fruit stones, nut shells, activated earth coal, synthetic organic polymers etc, regarded as a mixture of amorphous carbon and hydrocarbons. The activation process is carried out at temperatures of $800-1100^{\circ} \mathrm{C}$ in special ovens.

As raw materials for obtaining activated carbon are used different carbon-rich materials, for example - wood, peat, coal land [2]. To obtain activated carbon used in anti-gas masks and other specific uses, which should have increased strength and volume of micro-and super-micropores, coconut shell is used as raw material. Should be mentioned here the use of metal carbides, carbon black, lignin, used tires, waste from polyvinyl chloride production and waste from other synthetic polymers production [3].

Due to its physical and chemical properties of activated carbons are unique and ideal sorption materials that address wide range of issues of chemical and biological safety and the environment. Activated carbon is a highly porous carbon materials with highly developed internal surface. In the pore structure of activated carbon (volume of micropores and mesopores) is absorbed by all types of organic trace contaminants by adsorption forces [4].

It was established that with increasing ratio $\mathrm{H}: \mathrm{C}$ and $\mathrm{O}: \mathrm{C}$, the raw material activation is enhanced. However, a significant ratio requires the elimination from the raw material of a large proportion of volatile substances. The charcoal burning procedure is used for such purposes [5].

\section{Experimental Part}

As the raw material for obtaining of activated carbon, it was used the wood charcoal from the manufactured in Străşeni (MS) and Călăraşi (MC), that is quite widespread and more accessible than other materials.

Structural parameters and adsorption capacity of activated carbon depends on many factors, among which the most important are: activity time, activation temperature, steam flow, quality and origin of charcoal [6]. Structural parameters and geometric surface of carbonic adsorbents were determined from the adsorption - desorption isotherms of nitrogen at a temperature of $77 \mathrm{~K}$. Research has been conducted using an Autosorb 1 MP instrument. Analogical research was carried out for all obtained activated carbon samples. An example of such adsorption isotherms are shown in Figure 1. 


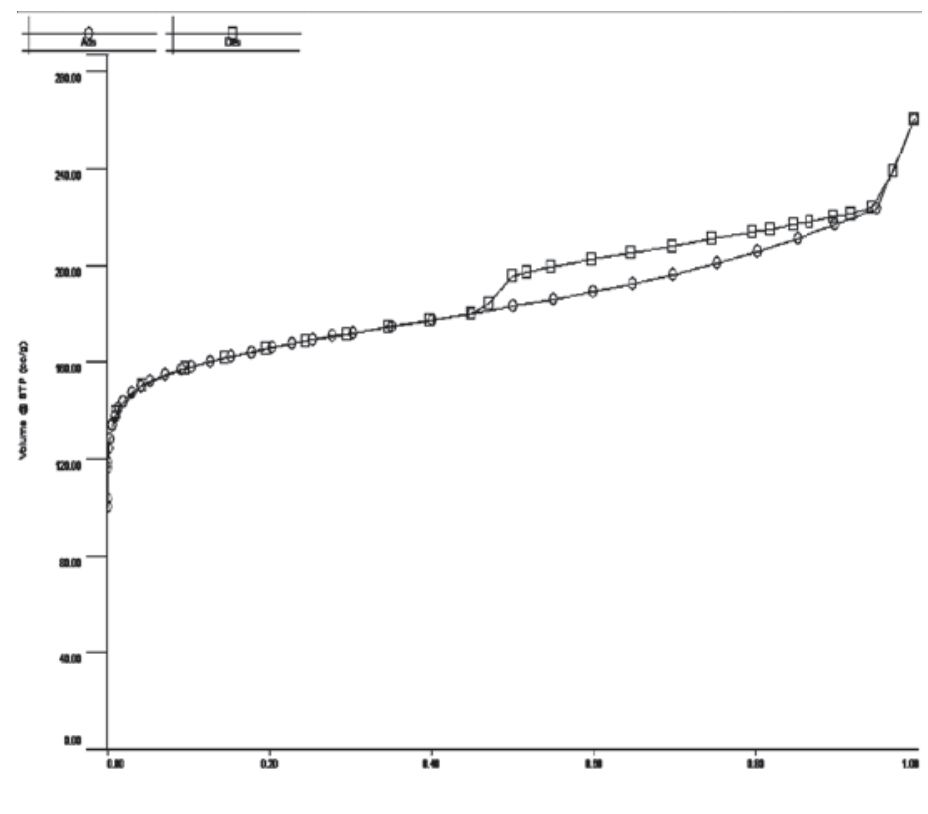

Fig. 1. Adsorption-desorption isotherms of nitrogen $(77 \mathrm{~K})$ on the activated carbon obtained from wood from (MS), activated during $30 \mathrm{~min}$ at $850^{\circ} \mathrm{C}$

Derived activated carbon pore sizes were determined from adsorption-desorption isotherms. An example of pore distribution curve of the dimensions is shown in Figure 2.

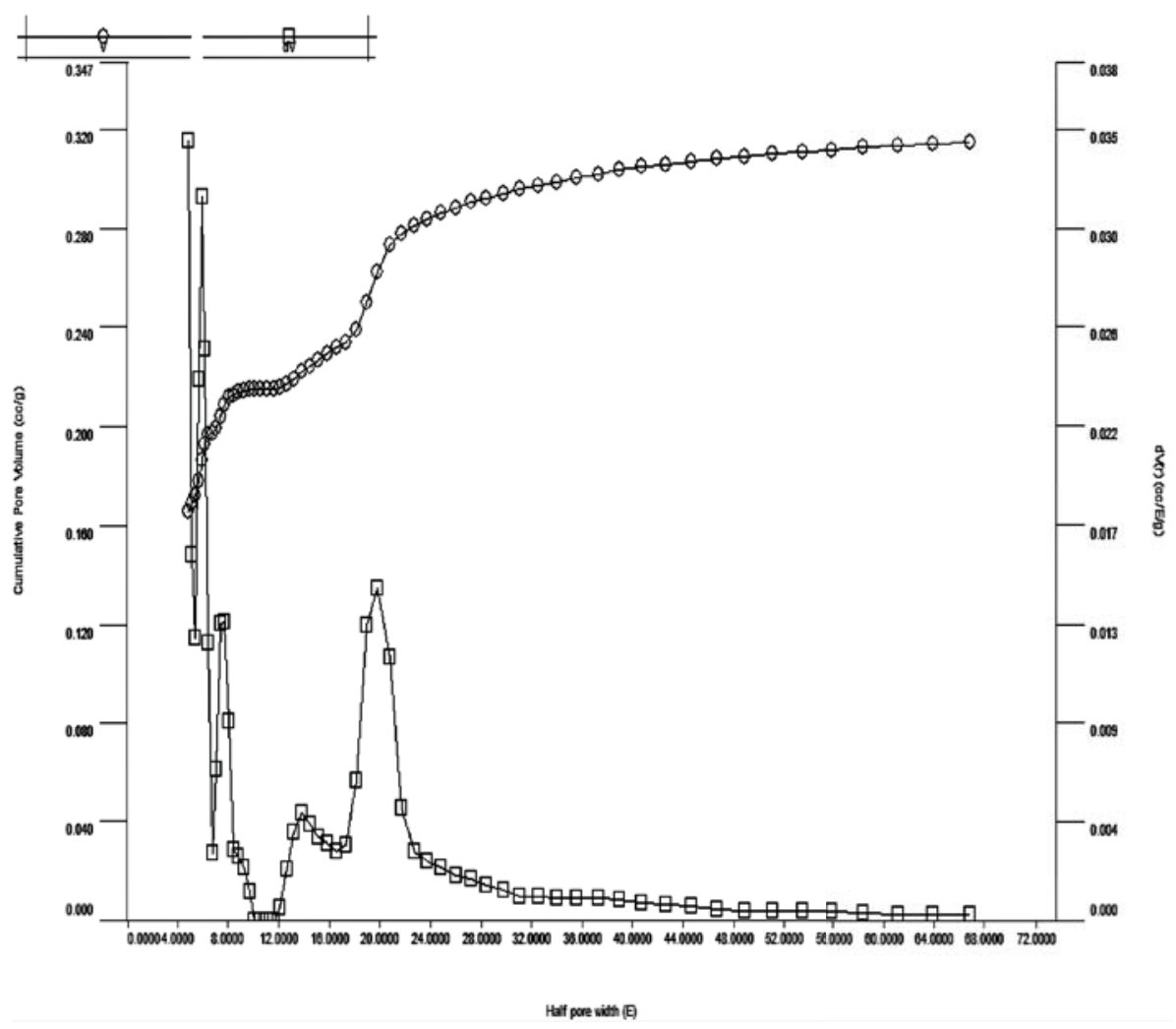

Fig. 2. The pore distribution curve on the sample sizes of activated charcoal obtained from wood from (MS), activated during $30 \mathrm{~min}$ at $850^{\circ} \mathrm{C}$

The geometric surface of new activated carbons was calculated using the BET equation in its linear form [7]: 


$$
\frac{\mathrm{P} / \mathrm{P}_{\mathrm{s}}}{\mathrm{a}\left(1-\mathrm{P} / \mathrm{P}_{\mathrm{s}}\right)}=\frac{1}{\mathrm{a}_{\mathrm{m}} c}+\frac{\mathrm{c}-1}{\mathrm{a}_{\mathrm{m}} c} \cdot \mathrm{P} / \mathrm{P}_{\mathrm{s}}
$$

Where $\boldsymbol{a}$ is the adsorption at relative pressure $\mathrm{P} / \mathrm{P}_{\mathrm{s}} ; \boldsymbol{a}_{\boldsymbol{m}}$-adsorption at pressure $\mathrm{P} / \mathrm{P}_{\mathrm{s}}=1 ; \mathrm{C}$ - constant that depends on the heat of adsorption and condensation of adsorbent.

In fact, the following correlation is set:

$$
\frac{\mathrm{P} / \mathrm{P}_{\mathrm{s}}}{\mathrm{a}\left(1-\mathrm{P} / \mathrm{P}_{\mathrm{s}}\right)} \text { from } \mathrm{P} / \mathrm{P}_{\mathrm{s}}
$$

As seen in Fig.3 it is a linear correlation.

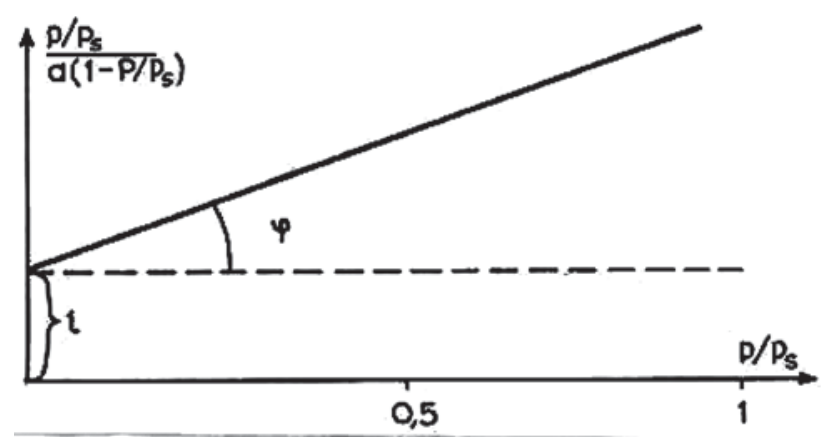

Fig. 3. Adsorption isotherm in the coordinates of the linearized BET equation.

The values $\boldsymbol{a}_{\boldsymbol{m}}$ and $\boldsymbol{C}$ from the presented equations are determined using this figure:

$$
\begin{array}{r}
\operatorname{tg} \varphi=\frac{\mathrm{c}-1}{\mathrm{a}_{\mathrm{m}} \mathrm{c}} \\
1=\frac{1}{\mathrm{a}_{\mathrm{m}} \mathrm{c}}
\end{array}
$$

The geometric surface $(S)$ of the activated carbons was calculated using the following correlation [8]:

$$
S=a_{m} \cdot \omega \cdot N
$$

where $\omega$ is the area occupied by an adsorption molecule in the compact monomolecular adsorption layer; $N$ is the Avogadro number.

Sorption volume $\left(\boldsymbol{V}_{s}\right)$ of the pores is calculated from the relation [9]:

$$
V_{s}=a_{m} \cdot V^{*}
$$

where $\boldsymbol{V}^{*}$ is the molar volume of the adsorbate.

\section{Results and discussions}

Results regarding geometrical surfaces, process efficiency, sorption pore volume as function of the activation temperature, the flow of water vapor during activation are presented in Tables 1-4.

Analysis of the results presented in the tables below allow to conclude that the geometric surface of activated charcoal depends on the time of activation, the water vapor flow, temperature of chemical process. Thus, increasing the duration of the activation temperature of $850^{\circ} \mathrm{C}$ from 30 to 90 minutes increases the geometric surface of the activated carbon from 625 to $947 \mathrm{~m}^{2} / \mathrm{g}$, for a water flow of $6 \mathrm{~mL} / \mathrm{min}$ (Table 1). 
Quality indices of activated carbons from wood charcoal (MS) obtained by physico-chemical activation at $850^{\circ} \mathrm{C}$ as function of activation time at a vapor flow of $6 \mathrm{~mL} / \mathrm{min}$

\begin{tabular}{|c|c|c|c|c|c|c|}
\hline Type of AC & Temperature, ${ }^{\circ} \mathrm{C}$ & Time, $\min$ & $\begin{array}{c}\text { Vapor flow, } \\
\mathrm{mL} / \mathrm{min}\end{array}$ & Rate, $\%$ & $\begin{array}{c}\text { Specific } \\
\text { surface, } \mathrm{m}^{2} / \mathrm{g}\end{array}$ & $\begin{array}{c}\text { Sorption } \\
\text { volume, } \mathrm{cm}^{3} / \mathrm{g}\end{array}$ \\
\hline S-1 & 850 & 30 & 6 & 78,1 & 625 & 0,402 \\
\hline S-2 & 850 & 50 & 6 & 69,2 & 633 & 0,416 \\
\hline S-3 & 850 & 70 & 6 & 43,4 & 833 & 0,574 \\
\hline S-4 & 850 & 90 & 6 & 21,3 & 947 & 0,631 \\
\hline S-5 & 850 & 120 & 6 & - & - & - \\
\hline
\end{tabular}

Table 2

Quality indices of activated carbons from wood charcoal (MS) obtained by physico-chemical activation at $750^{\circ} \mathrm{C}$ and $950^{\circ} \mathrm{C}$ as function of activation time at a vapor flow of $6 \mathrm{~mL} / \mathrm{min}$

\begin{tabular}{|c|c|c|c|c|c|c|}
\hline Type of AC & Temperature, ${ }^{\circ} \mathrm{C}$ & Time, $\mathrm{min}$ & $\begin{array}{c}\text { Vapor flow, } \\
\mathrm{mL} / \mathrm{min}\end{array}$ & Rate, $\%$ & $\begin{array}{c}\text { Specific } \\
\text { surface, } \mathrm{m}^{2} / \mathrm{g}\end{array}$ & $\begin{array}{c}\text { Sorption } \\
\text { volume, } \\
\mathrm{cm}^{3} / \mathrm{g}\end{array}$ \\
\hline $\mathrm{T}-1$ & 950 & 30 & 6 & 20,0 & 1249 & 0,825 \\
\hline $\mathrm{T}-2$ & 950 & 50 & 6 & - & - & - \\
\hline $\mathrm{T}-3$ & 750 & 30 & 6 & 69,0 & 563 & 0,340 \\
\hline $\mathrm{T}-4$ & 750 & 50 & 6 & 65,3 & 644 & 0,381 \\
\hline $\mathrm{T}-5$ & 750 & 70 & 6 & 59,3 & 660 & 0,490 \\
\hline $\mathrm{T}-6$ & 750 & 90 & 6 & 56,0 & 695 & 0,515 \\
\hline $\mathrm{T}-7$ & 750 & 120 & 6 & 52,3 & 716 & 0,556 \\
\hline $\mathrm{T}-8$ & 750 & 180 & 6 & 36,9 & 889 & 0,679 \\
\hline
\end{tabular}

Geometric surface value of carbonic adsorbents increases under similar activation conditions from 643 to 1126 $\mathrm{m}^{2} / \mathrm{g}$ increasing the flow of water vapor from $6 \mathrm{~mL} / \mathrm{min}$ to $12 \mathrm{~mL} / \mathrm{min}$ (Table 3 ).

Table 3

Quality indices of activated carbons from wood charcoal (MS) obtained by physico-chemical activation at $850^{\circ} \mathrm{C}$ as function of activation time at a vapor flow of $12 \mathrm{~mL} / \mathrm{min}$

\begin{tabular}{|c|c|c|c|c|c|c|}
\hline Type of AC & Temperature, ${ }^{\circ} \mathrm{C}$ & Time, $\mathrm{min}$ & $\begin{array}{c}\text { Vapor flow, } \\
\mathrm{mL} / \mathrm{min}\end{array}$ & Rate, $\%$ & $\begin{array}{c}\text { Specific } \\
\text { surface, } \mathrm{m}^{2} / \mathrm{g}\end{array}$ & $\begin{array}{c}\text { Sorption } \\
\text { volume, } \mathrm{cm}^{3} / \mathrm{g}\end{array}$ \\
\hline D-1 & 850 & 30 & 12 & 51,3 & 643 & 0,406 \\
\hline D-2 & 850 & 50 & 12 & 44,4 & 892 & 0,683 \\
\hline D-3 & 850 & 70 & 12 & 30,0 & 963 & 0,755 \\
\hline D-4 & 850 & 90 & 12 & 18,8 & 1216 & 0,837 \\
\hline D-5 & 850 & 120 & 12 & 6,0 & 1007 & 0,783 \\
\hline
\end{tabular}

This is explained by the fact that increasing water flow leads to higher vapor mass which reacts more intensely with amorphous carbon, volatile substances from charcoal shifting chemical equilibrium of reactions to right.

$$
\begin{aligned}
\mathrm{C}\left(\text { amorphous carbon) }+\mathrm{H}_{2} \mathrm{O} \stackrel{\mathbf{t}^{\circ} \mathrm{C}}{\longrightarrow} \mathrm{CO}+\mathrm{H}_{2}+\Delta \mathrm{H}\right. \\
\mathrm{C}_{\mathrm{x}} \mathrm{H}_{\mathrm{y}} \mathrm{O}_{\mathrm{z}} \text { (volatile substances) }+\mathrm{H}_{2} \mathrm{O} \stackrel{\mathrm{t}^{\circ} \mathrm{C}}{\longrightarrow} \mathrm{XCO}+\mathrm{YH}_{2}+\Delta \mathrm{H}
\end{aligned}
$$


Quality indices of activated carbons from wood charcoal (MC) obtained by physico-chemical activation at $850^{\circ} \mathrm{C}$ as function of activation time at a vapor flow of $6 \mathrm{~mL} / \mathrm{min}$

\begin{tabular}{|c|c|c|c|c|c|c|}
\hline Type of AC & Temperature, ${ }^{\circ} \mathrm{C}$ & Time, $\min$ & $\begin{array}{c}\text { Vapor flow, } \\
\mathrm{mL} / \mathrm{min}\end{array}$ & Rate, $\%$ & $\begin{array}{c}\text { Specific } \\
\text { surface, } \mathrm{m}^{2} / \mathrm{g}\end{array}$ & $\begin{array}{c}\text { Sorption } \\
\text { volume, } \mathrm{cm}^{3} / \mathrm{g}\end{array}$ \\
\hline C-1 & 850 & 30 & 6 & 70,6 & 580 & 0,322 \\
\hline C-2 & 850 & 50 & 6 & 69,0 & 698 & 0,425 \\
\hline C-3 & 850 & 70 & 6 & 54,4 & 807 & 0,612 \\
\hline C-4 & 850 & 90 & 6 & 44,4 & 794 & 0,592 \\
\hline C-5 & 850 & 120 & 6 & 30,3 & 649 & 0,624 \\
\hline
\end{tabular}

Increasing geometric surface of activated carbons is synchronized by the increase of pores sorption volume. Thus, sorption pore volume increases from 0.402 to $0.631 \mathrm{~cm}^{3} / \mathrm{g}$ for a water flow of $6 \mathrm{~mL} / \mathrm{min}$ (Table 1 ) and from 0.406 to $0.837 \mathrm{~cm}^{3} / \mathrm{g}$ for a water flow of $12 \mathrm{~mL} / \mathrm{min}$ (Table 3). A special role in the process of obtaining activated carbon is played by the activation temperature. Thus, the results presented in tables 1 and 2 clearly demonstrates that increasing activation temperature under the same conditions leads to increased quality indicators of activated carbons. Increasing the activation temperature from $750^{\circ} \mathrm{C}$ to $950^{\circ} \mathrm{C}$, leads to the increase of activated carbon geometric surface from 563 to $1249 \mathrm{~m}^{2} / \mathrm{g}$, for $30 \mathrm{~min}$ of activation and a vapor flow of $6 \mathrm{~mL} / \mathrm{min}$. Under the same conditions, sorption volume of carbonic adsorbents increases from 0.340 to $0.825 \mathrm{~cm}^{3} / \mathrm{g}$. This is explained by the fact that increasing the activation temperature increases the diffusion coefficient of water vapor in the porous structure of charcoal, which interacts more intensely with amorphous carbon atoms and volatile substances of charred wood.

Analysis of the results presented in Tables 1-4 reveals that increase of the geometric surface and pore volume of activated carbons is proportional to the increase in temperature and activation time up to certain values and then these indices decrease. This is explained by the fact that under such conditions there is an intense oxidation of carbon atoms in the graphite structure of charcoal. Another quality index that influences the efficiency of carbonic adsorbents production is the rate of activated carbon production process. This parameter decreases proportionally with increasing time, activation temperature and water vapor flow. The rate of activated carbon production process decreases with increasing specific surface area and pore volume of carbonic adsorbents.

\section{Conclusions}

1. Quality indices of carbonic adsorbents can be programmed depending on the application, by varying the temperature and activation time and the flow of water vapor.

2. Quality of activated carbons, determined and presented in the current paper, shows that the charcoal obtained from Străşeni wood and that obtained from Călăraşi wood represents a good and cheap source of obtaining carbonic adsorbents.

\section{References}

[1]. Kinle, H.; Bader, E. Activated carbons and their industrial uses/ In Russian L.: Himia, 1984, pp. 216.

[2]. Kapil M.; Sunny E.; Meyyappan M. et al. Coal as a carbon source for carbon nanotube synthesis. Carbon, Volume 50, Issue 8, July 2012, pp. 2679-2690.

[3]. Lupaşcu, T . Activated carbon from vegetal raw materials. Monograph/ In Romanian L.: ÎEP: Ştiința, Chişinău, 2004, pp. 224.

[4]. Adsorption, adsorbents and adsorption processes in nanoporous materials/ Collective volume, Moscow, 2011, pp. 469-474.

[5]. Noriyuki Y.; Motoi M. Carbonization of bamboo and consecutive low temperature air activation. Wood Sci Technol, 45, 2011, pp. 803-804.

[6]. Samonin, V.; Podvyaznikov M.; Nikonova V. et al. Sorbent materials, unit products and controlled adsorption processes / In Russian L.: SPb.:Nauca, 2009, pp. 271.

[7]. Kelitzev, N.V. Bases of the absorption technique/2 ${ }^{\text {nd }}$ edition.//M: Himia, 1984, pp. 592.

[8]. Petuhova, G.A.; Polyakov, N.S.; Lupaşcu, T.G. Estimation of porous structure of activated carbons//Izv. ASM, Chem series. 1995, №10, pp. 1934-1936.

[9]. Lupaşcu, T. Obtaining activated carbon technologies and their use in processes of potable surface water and groundwater// In Romanian L.: Mater. Simpoz. "Mediul şi Industria”, Bucureşti 24-26 septembrie 1997, pp. 1-8. 